ÉGYPTE monde arabe

\section{Égypte/Monde arabe}

13 | 2015

Nouvelles luttes autour du genre en Egypte depuis 2011

\title{
Perceptions and management of gender roles and dynamics inside OpAntiSH Intervention Teams in Cairo
}

Perception et gestion des rôles et dynamiques de genre dans les équipes

d'intervention de OpAntiSH, au Caire

Leslie Piquemal

\section{OpenEdition}

Electronic version

URL: https://journals.openedition.org/ema/3540

DOI: $10.4000 /$ ema. 3540

ISSN: 2090-7273

\section{Publisher}

CEDEJ - Centre d'études et de documentation économiques juridiques et sociales

\section{Printed version}

Date of publication: 10 November 2015

Number of pages: 133-152

ISBN: 9782905838865

ISSN: 1110-5097

\section{Electronic reference}

Leslie Piquemal, "Perceptions and management of gender roles and dynamics inside OpAntiSH Intervention Teams in Cairo", Égypte/Monde arabe [Online], 13 | 2015, Online since 10 November 2017 connection on 07 July 2022. URL: http://journals.openedition.org/ema/3540 ; DOI: https://doi.org/ 10.4000/ema.3540 


\section{PERCEPTIONS AND MANAGEMENT OF GENDER ROLES AND DYNAMICS INSIDE OPANTISH INTERVENTION TEAMS IN CAIRO}

\section{ABSTRACT}

$A_{\text {f }}$ number of anti-sexual harassment and anti-sexual violence initiatives were formed by Egyptian citizens after 2011 to confront the rising tide of gender-based violence against women in the public sphere. Among those focused on direct intervention in cases of mob sexual assault in mass gatherings in Tahrir Square (Cairo), Operation Anti-Sexual Harassment/Assault (OpAntiSH) was the only one that always integrated male and female volunteers in all teams, including Intervention. This study of the management and perceptions of gender dynamics by volunteers inside OpAntiSH's Intervention teams in 2012-14, is based on micro-sociological analysis of the data gathered through participant observation and semi-structured interviews during this period.

This paper first addresses women volunteers' motivations - based on their own narratives - for joining Intervention teams, a choice that could be viewed as counter intuitive or frowned upon in Egyptian society, in which the dominant model of gender roles remains quite close to the model of hegemonic masculinity. Many framed this choice within an identity-based reading of the phenomenon of mass sexual assaults as attacks on all women as political agents in the public sphere, and their response as a means of resistance and reclaiming agency. Women's presence in Intervention teams was initially an issue for many volunteers, who developed certain techniques and coping strategies to manage it. These included specific ways of performing gender within the group that differed from their practices in other contexts, and various approaches to the negotiation of gender roles within teams. Intervention involved a broader learning process about gender for some volunteers, whose view of women's presence in teams evolved, though it remained somewhat of 
an issue for other "silent dissenters" of sorts. Ultimately, the particularity of the OpAntiSH experience is connected to the creation of a social sphere of gender equality and solidarity, geared toward the joining of forces between men and woman as equals, to fight mass sexual violence in the public sphere, within a very non-egalitarian society.

Operation Anti-Sexual Harassment/Assault (known as OpAntiSH or al-Quwwa dedd al-taharrush) ${ }^{1}$ is a collective founded in November 2012 to fight the growing phenomenon of extremely violent mass sexual assaults against women during large gatherings in or around Tahrir Square, in central Cairo. ${ }^{2}$ Human rights groups and activists have reported them repeatedly during large political gatherings in this area since 2011. In fact, such cases had sporadically occurred in different crowd contexts (protests, football games, holiday crowds, concerts) in the public sphere since the mid-2000s in Egypt. Perpetrators - mostly all male - have included police or military forces, "baltagiyya" ("thugs," civilians serving as police auxiliaries), young boys on the street, or men and youths attending a cultural or political event. ${ }^{3}$ The mob assaults in Tahrir Square since 2011 have ranged from mass groping to the stripping and gang rape of women using hands, and occasionally blunt or sharp objects as well.

This type of assault has rarely been reported to the police or media by survivors, most expecting they would be blamed to some extent by relatives or peers, and would not receive support. The frequency and severity of these attacks has tended to be minimized - not least through the use of the same term taharrush (harassment) for sexual assault and rape (individual or

1. https://www.facebook.com/opantish.

2. For more information, refer to OpAntiSH, Amnesty International and Human Rights Watch's reports and videos listed in the "References" section of this article. The introductory chapter of this journal issue provides additional information on gender-based violence in the public sphere in Egypt since 2011.

3. State-sponsored actors have been perpetrators or passively complicit in several confirmed cases since the mid-2000s; sexual violence was clearly used as a political instrument against women protestors on some occasions, to disperse them and deter them from mobilizing and protesting again, most notoriously in the "Black Wednesday" case of 2005. However, individual citizens have also apparently groped and assaulted women spontaneously in large festive gatherings during the 2000s. Since 2011, gender-based violence in the public sphere has been used by security forces or civilians acting upon instructions from some influential party associated to the authorities, as one of a range of tools to break, humiliate and punish protestors. In Tahrir Square, sexual violence against women has been used to this end, as well as to terrorize and intimidate female protestors and evict them from the public sphere of protest, with a view to weakening mobilization and possibly discrediting a protest movement. Scholar Mariz Tadros $(2013,2014,2015)$ in particular researched this practice in spite of the difficulty of collecting hard evidence against perpetrators. However, civilian bystanders undoubtedly have joined in mob sexual assaults there, when they did not actually begin them themselves. The longer these crimes continued unpunished, the more Tahrir became notorious in Greater Cairo as a place where they could be committed with impunity. Ultimately, a continuum of violent practice has emerged in Tahrir Square with various combinations of civilian perpetrators, State negligence and/ or complicity, and State-orchestrated violence. Zaki \& Abd elHameed (2014) give one of the most thorough overviews of the phenomenon, its causes and dynamics. 


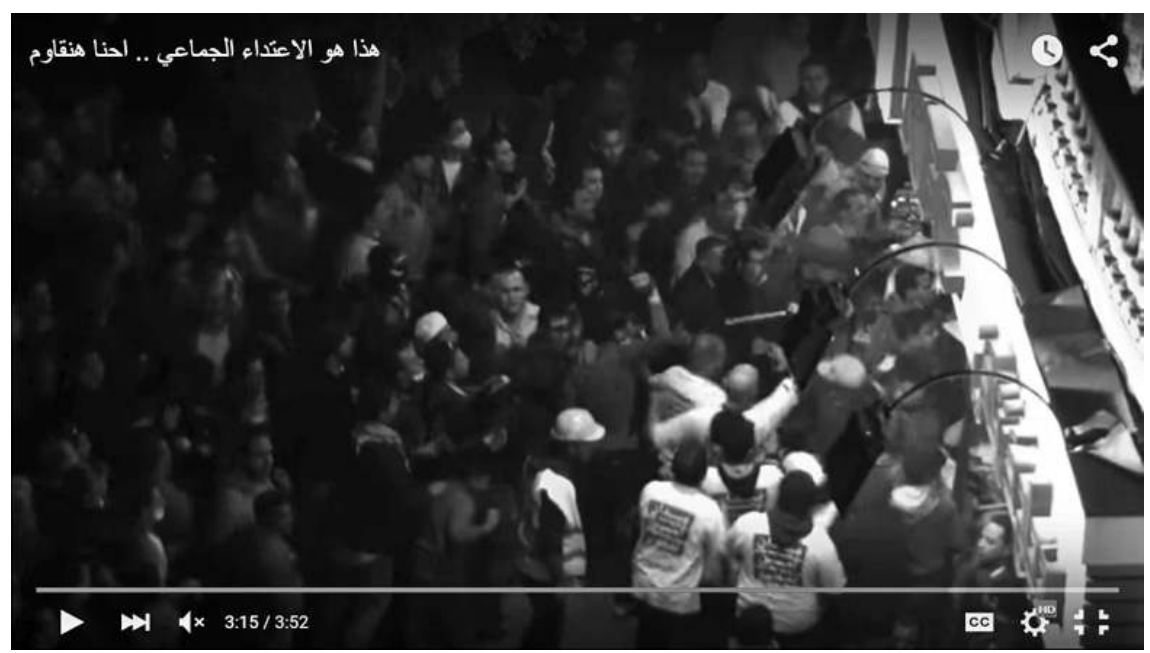

Screenshot from the OpAntiSH video "هذا هو الاعتداء الجماعي .. احنا هنقاوم" (This is sexual harassment/assault. We will resist"), uploaded Feb. 1, 2013, https://www.youtube.com/ watch?v=KZyo74ESr2s. The footage was recorded from a building overlooking Tahrir Square. OpAntiSH Intervention volunteers are wearing white T-shirts with red logos.

collective) in the public sphere as well ${ }^{4}$ - or denied. State authorities long avoided acknowledging this phenomenon. More recently, they have sometimes noted its occurrence, often while blaming women for attending mass gatherings in areas known to be dangerous. Security forces have tended to be uncooperative toward survivors (when they were not actually perpetrators or complicit in such crimes). The mainstream media provided very little coverage, and virtually none of good quality until after 2011.5 This social environment has facilitated the escalation of endemic sexual harassment to paroxysms of mass violence in specific public locations ${ }^{6}$ due to victim-blaming and impunity of perpetrators, as well as minimization and excusing of harassment and assault $^{7}$ in the street, workplace and public transportation. Frank discussion of this phenomenon's more violent aspects as a social problem long remained relatively taboo for anyone other than rights activists. ${ }^{8}$

4. The use and misuse of terminology is part of the phenomena of minimization of gender-based violence and victim-blaming. The term taharrush gamâ $̂$ (literally "collective harassment") has become the commonest one for mass sexual assault of women. 5. In addition to condoning or minimizing sexual assault, some media discourse features hate speech against women (see AP, "Egyptian clerics' fatwas encourage sexual assaults, murder," Feb. 7, 2013).

6. Nazra for Feminist Studies, "Position Paper on Sexual Violence against Women...," Feb. 4, 2013.

7. Rape and indecent assault (hatk 'ird) are forbidden by law in Egypt but until 2014, sexual harassment was not criminalized; Furthermore, only forcible penile penetration of a woman is legally classified as rape - a much narrower definition than that of international human rights standards.

8. Kirollos, 2013. 
In 2012, several volunteer groups were created to confront the growing wave of mass sexual assaults and rapes in Tahrir Square during large political gatherings and/or to engage the public in order to raise awareness of the problem of street harassment and assault. This movement has been quite diverse in terms of discourse, methods of organization, levels of feminist consciousness, and intervention methods on the ground. Groups also differ "in the extent to which their feminist and revolutionary consciousness overlap, and in their conceptions of how to solve the problem" ${ }^{\prime 9}$ of mass sexual assaults.

The collectives with a focus on direct intervention to stop these assaults initially elected to form all-male teams of volunteers, assuming the risk of sexual assault would be too high for female volunteers - except for Operation Anti-Sexual Harassment/Assault $(\mathrm{OpAntiSH})$. The activists and human rights workers who first formed this collective can be described as feminists - whether or not they identified explicitly as such - since they consider women's rights a high priority within their political struggle and believe in full equality of rights for men and women. It was created with support from some of Egypt's most feminist women's rights and human rights NGOs ${ }^{10}$ and differed from other groups on "how to minimize the danger [to volunteers] without enabling the patriarchal conception that women in public space need 'protection' "11 from men. OpAntiSH's position was to reject the representation of men as "protectors" and to encourage female volunteers to participate as equals in the entire process of rescuing mob assault survivors, including Intervention. This approach was at odds with dominant social models of gender roles, as it involved women volunteers taking significant physical risks for the sake of saving others. Yet OpAntiSH volunteers were also members of society, often affected in some way by patriarchal conceptions of gender roles. This paper addresses female volunteers' motivations for joining OpAntiSH Intervention teams, how male and female teammates have perceived their roles, and how they have viewed and managed issues connected to having mixed-gender teams. ${ }^{12}$

A more empirical approach will be followed, so as to give more of a voice to the actors themselves. There is a dearth of scholarship on OpAntiSH and other recent mobilizations for emergency intervention to fight cases of mass sexual assault in political gatherings in Egypt. Access to these new groups in a time of crisis in Egypt has been difficult; then, the cases in Tahrir Square have waned since mass protests and gatherings have become rare there; finally, police control of the area has become very tight, so informal groups have had

9. Zaki \& Abd elHameed, 2014.

10. the Egyptian Initiative for Personal Rights (http://eipr.org/en) and Nazra for Feminist Studies (http://nazra.org/).

11. Langohr, 2013.

12. I will mostly use the past tense in the rest of this paper because OpAntiSH became inactive in 2014 due to changing circumstances and issues connected to access to Tahrir Square, although the collective has not been dissolved. 
difficulty accessing it. OpAntiSH and some others have become mostly inactive on the ground, making it difficult for any new fieldwork to be carried out on those collectives. Research in this field has focused on the question of women and the revolution, the problem of sexual harassment, the multiplication of mob sexual assault cases, State feminism versus grassroots initiatives... However, some gaps in this new field of sociological and political knowledge remain difficult to fill, in particular - due to access issues - the micro-sociological or ethnographical study of informal groups fighting gender-based violence in the public sphere. Except for the Gulabi Gang in India, ${ }^{13}$ few such informal collectives involving women in the developing world have been studied in depth. Among such Egyptian initiatives, which appeared in a politically volatile context, some have proved rather ephemeral; it is possible that no further scholarship may be produced at all, particularly on the groups which are no longer active. Therefore, this paper will focus primarily on addressing this gap in the literature through an essentially empirical case study of the functioning of OpAntiSH in Egypt.

This analysis is based on participant observation within OpAntiSH between December 2012 and January 2014, and on semi-structured interviews with Intervention volunteers. It seemed unwise and unproductive for the group for me to consider changing my mode of participation as a volunteer (which predated the research specifically about intervention team dynamics) in hopes of gather more data about intervention team dynamics through direct participant observation in their work in Tahrir Square. The very dangerous situation on the ground did not allow for untrained observers to accompany teams at work: I would have had to become a fully active team member. But my initial choice to join other teams ${ }^{14}$ than Intervention had been based on careful assessment of my abilities, which had not changed since then. Hence, my approach posed no major issues of personal safety for me to consider in carrying out the research; but it also precluded my conducting participant observation inside Intervention teams at work in Tahrir Square, except as they waited on the sidelines on quieter nights. Thus, much of the material used here comes from individual volunteers' accounts of how they perceived and experienced Intervention, in addition to the knowledge of the collective provided by my own observations inside OpAntiSH and on the periphery of intervention activities.

Naturally the question of the reflexive dimension in my approach to the work had to be considered. However, it was less an issue of my gender

13. The Gulabi Gang are a movement of Indian women activists; it started as a group of women noted for their pink (gulabi) saris who confronted oppressive and physically abusive men in Bundelkhand, Uttar Pradesh. It grew quickly and has become active across North India. See http://www.gulabigang.in/.

14. I was a Safety team volunteer from late November 2012 till early July 2013, then joined the Core group (coordinators). 
identity $^{15}$ as it was about my belonging to the group in which I was studying perceptions and dynamics of gender: I had to contend with the issue of my own identification with my object of study. Taking part in OpAntiSH activity in such a time of crisis as 2012-13 tended to produce a high degree of emotional involvement; many had a strong feeling of belonging and loyalty to the collective. It required an effort to distance myself emotionally while analyzing data or writing. However, this aspect of researcher subjectivity was also difficult to avoid, since my access to information was largely contingent upon my status as a member of the collective, which facilitated a rapport of trust with Intervention volunteers I interviewed. The emotional and psychological cost of the experiences they had had, made most of them reluctant to be interviewed, which might involve reliving what they preferred to forget. Their trust in me as a member of OpAntiSH allowed me to reassure them I would not ask questions in a sensationalistic, tabloid-journalist style they might dread. Also, our shared membership in the group meant a sort of guarantee I was committed to certain ethical norms and would not misquote them, or identify them and report their statements to the mainstream media, for instance. In short, it seems unlikely a scholar from outside the group would have managed to collect as much data in this way, particularly through in-depth interviews.

Restrictions connected to availability, confidentiality and consent did not permit the constitution of a representative sample of the limited population of Intervention volunteers, though a range of individuals with different profiles and views were interviewed. Aside from points noted by all or most interviewees, the observations made in this paper about details of team dynamics are not to be taken as definitive and universally valid. The volunteers in a team were not always all the same; several Intervention teams could be on the ground at the same time, leading to further differences connected to individual and team variations. In such a chaotic context as Intervention in cases of mob sexual assault, perceptions of gender roles and dynamics must necessarily be subjective - collected individual accounts and interpretations are, no doubt, the most likely to shed light on practices and representations.

In short, several dimensions of reflexivity had to be taken into consideration at all times during the research process: mine as well as and the interviewees' about themselves and about each other. But in spite of the ethi$\mathrm{cal} /$ methodological questions this raised, the dearth of thorough research about anti-mob sexual assault collectives in Egypt and the absence of any scholarship at all on the aspect I was focused on - and how unlikely it seemed anyone from outside the collective might be able to study it - convinced me the potential value of my work would outweigh the drawbacks.

15. I researched views of the identity and roles of both genders, as well as their interactions. Ultimately, a majority of scholars in my position would also identify as either male or female; this aspect of subjectivity would have been difficult to avoid for most. 


\section{WHY WOMEN JOINED OPANTISH INTERVENTION TEAMS: GENDER IDENTITY AND AGENCY}

Female members of OpAntiSH's Intervention teams expressed different motivations for their decision to volunteer for this task. Many saw the mob sexual assaults in Tahrir Square as part of the phenomenon of sexual harassment - albeit pushed to its extreme - and this phenomenon "is our issue, it's the cause of every girl who goes through this." 16 Being exposed to "ordinary" street harassment in their daily lives and resisting it meant they already felt affected by this phenomenon and involved in the fight against it.

One volunteer described the authorities' attitude toward the attacks as a presage of further escalation: some victim-blaming statements by government bodies ${ }^{17}$ encouraged attackers to commit such crimes again. To her, what already constituted a form of collective punishment of women, a symbolic attack on them as subjects in the public sphere, and the embodiment of misogyny in society, "could possibly get worse, maybe like witch burnings in public squares." 18 Thus, some framed their decision to join OpAntiSH intervention teams as a response to a phenomenon experienced as a symbolic "eradication of who I am from public space,"19 as one put it - a personal attack. This aspect was felt more clearly and acutely by those who had already survived mass sexual assault, knew a survivor or had witnessed a case. They expressed a feeling of identification with survivors and connected it to the perception that what was occurring with increasing frequency and violence in Tahrir Square represented a direct, immediate, systematic threat to themselves and to all women. Defending women under attack in Tahrir Square was meant as a form of collective self-defense.

Some also described the Tahrir attacks as a particular kind of gender-based violence in the public sphere, specifically in the framework of the Egyptian revolution (as a long-term process): ${ }^{20}$

\footnotetext{
“As a matter of principle, that shouldn't be happening. I also felt they [attackers] were trying to push women out of the revolution in general. I felt it was metaphorical: they wanted to us out of the Square and off the street altogether. So I felt [joining OpAntiSH] was an important battle on the revolutionary level, and also on a human level." 21
}

Female volunteers who saw the mob assaults as a social and symbolic attack on Egyptian women as persons and also a political attack on them as

16. Samia, interview, Dec. 5, 2013. All interviewees' names have been changed.

17. Egypt Independent, Feb. 11, 2013.

18. Passant, interview, Nov. 20, 2013.

19. Ibid.

20. Hala, interview, Dec. 5, 2013.

21. Noha, interview, Dec. 1, 2013. 
free political agents, an attempt to drive them out of the public sphere, described a particular sense of urgency ${ }^{22}$ about actively resisting what they perceived as an attack on several aspects of their identity as women, citizens and revolutionaries. To one, resisting personally was the only option: "It was important from the very beginning to have women in Intervention [teams] because this is our war and no one is going to fight it for us. If we let men fight it for us, then we'll be kicked out of everything pretty soon." ${ }^{23}$ Several women explained it seemed counter-intuitive to retreat from Tahrir Square and have all-male teams resist these attacks in their stead.

Others saw their decision to join OpAntiSH as a choice among several options. Aware of other groups fighting the assaults in Tahrir, they chose OpAntiSH because it did not orient new volunteers toward either Intervention or Safety teams based on gender. The sense of gender equality felt liberating to some: "making sure there is no patriarchy, no one trying to protect you, no one telling you what to do ...is amazing." 24 For a few, it was about more than empowerment and freedom of choice, though. One recounted having initially put pressure on herself to prove a point about gender equality, then gradually changing her mind:

"At the beginning, I was in an Intervention team just to prove to myself that I can do it, just like a man... What's wrong with girls being in the Intervention team, anyway? (...) Now I'm easier on myself, I don't have to be in the street to prove I'm just like a man and I can do it too. I can choose to be in the street, I can choose to be in the safe house, I can choose to be in my house and not show up at all." ${ }^{25}$

Several women mentioned breaking the fear of sexual assault as a factor that motivated them to join Intervention. Volunteering was a way of refusing to "always be the object of other people's actions" and of feeling stronger, feeling they were "able to take control of the situation," reclaiming their sense of agency against the menace of sexual violence, as well as intimidation and objectification in general in their daily lives. ${ }^{26}$ It was understandable, a volunteer explained, for women to fear the risks involved in Intervention more than men because they were targeted sexually in Tahrir Square, in addition to the risk of non-sexual violence male volunteers faced too. ${ }^{27}$ Sexual assault and rape is one of the ultimate threats women are brought up to dread, in Egypt as

22. Mona, interview, Dec. 29, 2013.

23. Leila, interview, Dec. 5, 2013.

24. Noha, interview, Dec. $1,2013$.

25. Manal, interview, Aug. 25, 2013.

26. Dina, interview, Nov. 20, 2013.

27. In fact, some male volunteers also reported they had been groped and harassed at times during Intervention. However, none of them expressed belief or fear they might be subjected to mob sexual assault and rape themselves; they underlined these practices specifically targeted women. While we cannot exclude the possibility the crime could be perpetrated against men, volunteers apparently perceived this risk as (either mostly or exclusively, depending on the person) one that concerned women. 
in many other countries, due to the social construction of femininity, selfworth and social standing as tied to women's sexual status and reputation. So "we have to overcome [this fear]... We are threatened with this all the time, and if we don't break [this fear] inside ourselves," a volunteer explained, "if we are unable to face it, nothing will change." 28

\section{MEN, WOMEN AND THE ISSUE OF FEMALE VOLUNTEERS IN INTERVENTION}

Women's participation in OpAntiSH Intervention teams has been the subject of some controversy between volunteers on various occasions. Calls for volunteers on social media did not identify the collective as explicitly "feminist" (though no patriarchal discourse was used). ${ }^{29}$ Among the male volunteers who attended open meetings, some joined OpAntiSH rather than other collectives because they liked its egalitarian approach and saw the active involvement of women in their own defense as a positive step. ${ }^{30}$ But many joined simply because they were shocked at the graphic details of the sexual violence in Tahrir Square, and saw it as inhumane. In fact, some found it particularly detestable because it was violence against women as weaker beings in need of protection from men, the stronger, braver, more capable sex. A female teammate described their approach to volunteering thus:

"They are machos (zukouriyyeen). I'd notice they think we are girls so we are weaker, they think they are physically stronger so they are better, they think they are men so they know what they're doing - they've been in a lot of fights so they know what they're doing... It's machismo. It's a social thing." ${ }^{31}$

For these men, volunteering in Intervention could be qualified as a traditionally "virtuous" act because it involved carrying out the social duty of protecting (and saving) women: ${ }^{32}$ "the fact that what they do is saving girls - for some people this is very satisfying, this part about proving their masculinity," remarked Noha. ${ }^{33}$ Thus, some male volunteers joined OpAntiSH based on a reading of the crisis situation and of the nature of Intervention through the lens of what may be called hegemonic masculinity, "the pattern of practice... that allows men's domination over women to continue." 34

28. Leila, interview, Dec. 5, 2013.

29. This http://www.youtube.com/watch?v=Q0OID6QvoSw is an OpAntiSH call for volunteers in Arabic (accessed Aug. 26, 2014).

30. Islam, interview, July 30, 2013; Ammar, interview, Aug. 15, 2013; Sherif, interview, Aug. 3, 2013; and others.

31. Dina, interview, Nov. 20, 2013.

32. Of course, a few male volunteers had different or additional motivations.

33. Noha, interview, Nov. 20, 2013.

34. Connell \& Messerschmidt, 2005, p. 832. 


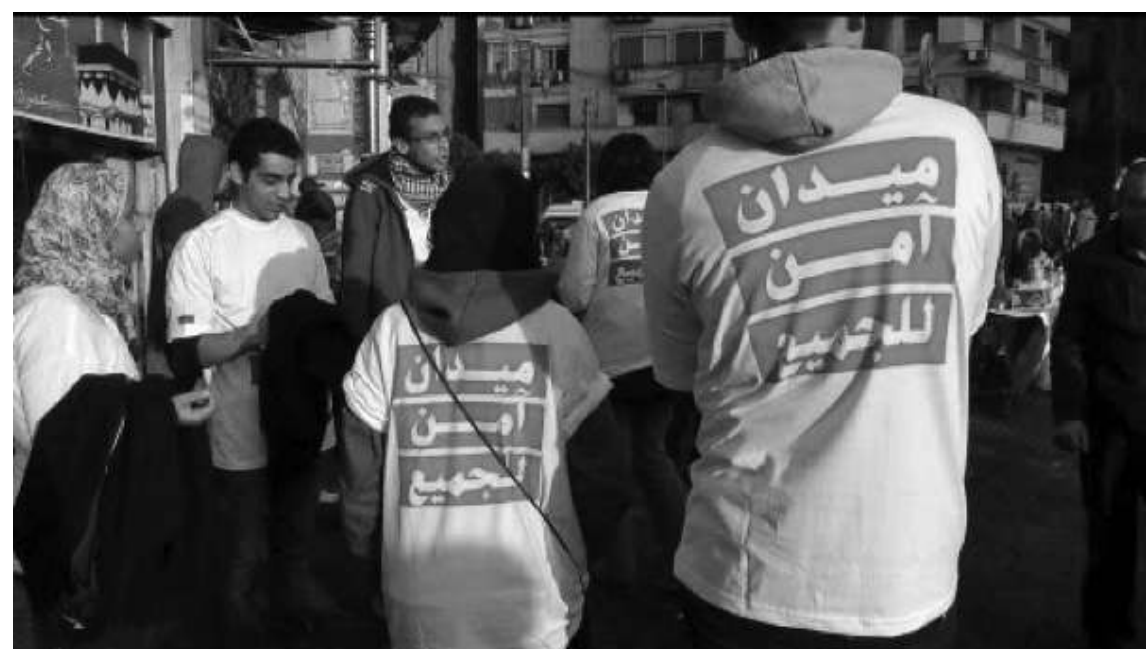

OpAntiSH volunteers at Tahrir Square, spreading information about mob sexual assault and hotlines, in the late afternoon on a protest day in winter 2013. Their T-shirts read "ميدان آمن "للجميع" ("A Safe Square for All")

Many of them were initially surprised to see women in Intervention. Team leaders and more experienced volunteers indicated they often managed such reactions by explaining that once the team reached a woman being assaulted, the female volunteers' presence was necessary to quickly gain her trust and cooperation with maneuvers to get her out. This tactical argument was initially more efficient in getting reticent men to participate in a mixed-gender team, than an argument based on the principle that every adult can and may take this risk, and that male teammates are not responsible by default for protecting female volunteers. Other men agreed with the latter argument and criticized their more conservative peers:

"These male volunteers who disagree [with women' participation in Intervention] at the beginning... think they're arguing for this position because as men, they're caring toward women. They don't know they're in the wrong place, because the organizers of OpAntiSH are feminists. (...) They should know they're not here to defend women 'because they're weaker than us', because they're 'not men'." 35

The fact that some male volunteers initially accepted their female teammates' presence primarily as a matter of tactical necessity, could sometimes be a source of complications; ${ }^{36}$ some tensions connected to gender dynamics appeared within teams. Several volunteers underlined the effects of stress and 
pressure on the ground ${ }^{37}$ in Tahrir Square in revealing such tensions. Male volunteers sincerely embracing egalitarian principles about women's ability to resist sexual violence themselves, could still find it difficult to resist the urge to act as protectors. ${ }^{38}$

Faced with a male teammate panicking and trying to push them back from the crowd, some female teammates felt they had to assert themselves forcefully, shouting or pushing teammates so as to be let through into the crowd. ${ }^{39}$ Many described male volunteers' acceptance of women's participation in Intervention as an ongoing process. ${ }^{40}$ In general, Intervention team members agreed that female volunteers found they had to demonstrate their abilities to their male counterparts, but their opinions varied on how far this process had progressed. Some felt women had to "prove themselves constantly" as capable in order to take part ; ${ }^{41}$ others thought that by late 2013 they had done so sufficiently. ${ }^{42}$

Women's representations of gender roles, identities and dynamics within Intervention often evolved as well. One female volunteer assumed at the start that women were to join Safety teams and that Intervention teams would be all-male, then later decided "to try Intervention herself" and realized she "saw a lot of girls really fitting in the Intervention team even though they're not guys." ${ }^{43}$ The OpAntiSH experience led her to question her initial assumptions about gender roles and to reflect on how her representations of action had been shaped by patterns of previously internalized "sex segregation" (as she called it).

Passant explained that having women in Intervention was initially "an uncomfortable thought" to her; she had felt conflicted though she supported it in principle, because

"... women are at such high risk being on the team - [l asked myself] is there another way? Should there be another way? What does it mean when you go into (the crowd)... and one of your team gets grabbed and taken away?... I felt, as important as it was to have women there, it was also a liability." 44

She recalled that when she became more physically fit, she felt stronger and joined Intervention after all, "because there were not enough women on the team"; eventually, she managed to deal with fears for other women. Her account shed light on the interplay of physicality and self-confidence, and the difficulty of managing tensions between egalitarian principles and fear for

37. Dina, interview, Nov. 20, 2013.

38. Nader, interview, Aug. 20, 2013.

39. Samia, interview, Dec. 5, 2013.

40. Ibid.

41. Abu-I-Hassan, conversation, Nov. 6, 2013.

42. Passant, interview, Nov. 20, 2013.

43. Noha, interview, Dec. 1, 2013.

44. Passant, interview, Nov. 20, 2013. 
others. It also underlines how even feminists may struggle with stereotypes related to gender. ${ }^{45}$ Passant and others noted team-building and shared experience showed them how each volunteer's attitude and ability to cope could make more of a difference than their physical and gender characteristics per $s e,{ }^{46}$ and to appreciate the importance of individualized interaction with peers. One woman explained how she realized she herself made assumptions based on gender stereotypes:

"On the 25th (of January, 2013), when we had to run to a house (with a survivor, for shelter from the mob)... one of the guys with us was crying his eyes out... I asked him, 'Are you OK?' He said, 'No, I'm crying because of everything I'm seeing!' I immediately responded - I was so stupid - 'It's OK, you can go back downstairs (to Tahrir Square).' And he said, 'No, I'm crying because I don't want to go downstairs! I don't want to go back out!'... I'd made the same mistake. I'd assumed that because he was a man, he'd want to go back out there. But in fact he was crying because it was all very traumatizing for him... I said, 'Don't, don't go back there..$^{\prime \prime} 47$

Not all female volunteers' views on gender roles evolved in the same way, however. All interviewees noted the importance of having female volunteers interact directly with a woman under mass sexual assault. But not all women expressed the same degree of interest in playing other roles in the team, or felt hostile to certain functions within the teams being determined by gender, ${ }^{48}$ even though they all stated women should have the right to participate in Intervention if they wish.

\section{PERFORMING GENDER, COPING STRATEGIES AND THE NEGOTIATION OF GENDER ROLES}

Many volunteers explained the process of women proving themselves to teammates was not as much about physical might as it was about courage, enduring acute pressure, and self-control - one of the traits most frequently noted by volunteers as a strength of female team members. ${ }^{49}$ Leila, one of the first Intervention team members, underlined the analogy with proving oneself in the context of clashes between protesters and police: "it's exactly like you have to prove yourself on the front lines: standing there a bit longer after they start the tear gas, to show that you can stand this, so people will take you seri-

45. Ibid.

46. Dina, interview, Nov. 20, 2013.

47. Manal, interview, Aug. 25, 2013.

48. Hala, interview, Dec. 5, 2013.

49. Noha, interview, Dec. 1, 2013; Dina, interview, Nov. 20, 2013. 
ously." To her, some female volunteers' demonstrating their abilities then allowed others to have more leeway to join Intervention more easily. ${ }^{50}$ She and others (male and female) mentioned their hope of one day training enough volunteers to form an all-female team, alongside the mixed-gender ones: this would conclusively demonstrate women's ability to fight the battle themselves.

Many accounts showed awareness of gender roles and dynamics being negotiated between men and women in Intervention teams in a number of ways which varied from team to team, in addition to their evolution over time. Some noted some female teammates were treated differently than others, due to logical variables such as motivation, experience and past behavior. ${ }^{51}$ But some observed that some male volunteers still treated some female teammates differently and "relied on them more" if they "looked fit, look masculine," but tried to send others who appeared more "girly and feminine" to sit upstairs in a building with mass assault survivors. If "a girl looks visibly scared, it's easy for them to control her role," Dina added. ${ }^{52}$

Some women responded to this by adapting their attitude and body language. Female volunteers "have to be stronger. Their body posture has to change, they have to stand up straight, to look sharp, to seem hot-tempered." Dina considered this change was "connected to something they have inside themselves already and want to let out. It's not something foreign to them." 53 In this sense, changes in women volunteers' attitude and manner would have been an expression of a different side of their personality, which was usually repressed in everyday life so as to conform to dominant social norms.

Another volunteer gave a different reading of her adjustments of body language and attitude. She associated these with a "disguise" she assumed during particularly difficult crisis periods for OpAntiSH by wearing masculine-looking clothes, so as to conceal her body shape and pass for a man as often as possible. She described these shifts in body language, attitude and dress as

"... one of the tricks I'd play on myself and on others... which is kind of like a bluff, basically. I'm returning to Tahrir Square to make a statement, to say that women are going to take up the fight (against sexual violence), but at the same time I'm actually disguised as a man. It's ridiculous." ${ }^{54}$

She called this "manning up," in order to minimize harm done to her by men in the crowd during the intervention process by disguising her gender identity. This performance was also to facilitate bonding with male teammates, which was important for the team to function well in a dangerous context.

50. Leila, interview, Dec. 5, 2013.

51. Mona, interview, Dec. 9, 2013.

52. Dina, interview, Nov. 20, 2013.

53. Ibid

54. Leila, interview, Dec. 5, 2013. 
Men, she explained, "are not used to bonding with women in these situations," but rather with other men; her acting and looking more masculine made it easier to build a comfortable rapport with them. ${ }^{55}$

These women agreed that female volunteers' adapted performance of gender during Intervention was intended for male teammates as well as the crowd. Inside teams, gender roles were something of "a game both sides (men and women) were playing" on some level. One volunteer remarked he sometimes noted similar changes in some of his male peers' demeanor and interpreted this as both men and women performing a more ostensibly "masculine" version of masculinity during Intervention. ${ }^{56}$ In fact, it is likely that these adjustments were also connected to the demographic many of them come from: urban, educated middle-class/upper-middle-class Egyptians aged 18 to 35 with an interest in socio-political issues, who are willing to face physical danger - in other words, the stereotypical "revolutionary" demographic:

"Our volunteers mostly come from the revolution: they are pro-revolution people who have been in clashes and all that. So this culture affects them. And we can't deny the revolution is building a kind of macho image, that of a hero who's always on the front line, never gets tired and knows how to use every kind of weapon - how to make a Molotov, how to use a flare, how to throw rocks, things like that. And this image affects OpAntiSH." ${ }^{57}$

In other words OpAntiSH volunteers, like others, have probably been influenced by this "revolutionary mystique" to some extent. Performing gender differently in a high-stress environment, as a coping strategy, could understandably be connected to such positive images that could make one feel stronger, more competent and self-assured.

\section{DISSENT, LEARNING AND CREATING A SPHERE OF GENDER EQUALITY}

Naturally, these gender dynamics are to be understood within the framework of the OpAntiSH social circle in general, and could be specific to it. For male volunteers, expressing admiration for female teammates during a meeting did not necessarily mean their viewpoint on gender roles in general had changed. It did not predict whether or not the admiration would wear off ${ }^{58}$ or what they thought of other women outside this context: ${ }^{59}$

55. Ibid.

56. Abu-I-Hassan, conversation, Nov. 6, 2013.

57. Leila, interview, Dec. 5, 2013.

58. Dina, interview, Nov. 20, 2013.

59. Shady, interview, Dec. 10, 2013. 
"[A male volunteer] is not going to change in one day... It would be a problem if he started dealing with the women in his life the same way... I believe he would still go home and be really protective of his sister, his mother or his girlfriend." 60

Several women emphasized the effect of peer pressure on male volunteers' behavior, explaining that deep down, some continued to believe women's presence in Intervention was a liability: ${ }^{61}$

"There's so much pressure in the group... Because it's so explicit, the guys... don't act patriarchal when we're around... But I don't know if that means that their viewpoint has changed, not all of them... Others are just working in a mixed-gender team because of the pressure for it to just be this way. They have to. It's very clear from the start that girls will be there, and if you don't like that, OpAntiSH is not where you belong." ${ }^{62}$

This pressure in favor of the gender equality principle in Intervention discouraged them from voicing dissent to it. Thus, the process of assertion and enforcement of OpAntiSH's norms allowed it to create a social sphere in which the dominant gender norms and roles in Egyptian society did not hold true:

"This is something good, for us to create a space in which equality is the norm and voicing something against it, is something you have to think twice about - at a time when society is the complete opposite: voicing equality is something you cannot even think about because it will get you into a fight." ${ }^{63}$

Leila acknowledged this involved some degree of confrontation, but saw it as a necessary part of the process of creating a progressive social sphere that was a "safe and free space" for women's priorities in the fight against sexual and gender-based violence. In fact, power is inevitably a factor on some level in group dynamics; "there are norms and standards; if you break them, you're out. You can be made an outcast or we can have a fight... Part of OpAntiSH is creating this space in which the norm is respecting women, not saying homophobic things..." 64 The "alienation" of some male volunteers one woman mentioned ${ }^{65}$ was presumably connected to their feeling of disempowerment as individuals influenced by dominant, patriarchal role models, but whose views were treated as deviant inside the collective.

As OpAntiSH integrated new volunteers, some fit in easily while others were encountering new behavioral norms. Some of those conformed

60. Mona, interview, Dec. 9, 2013.

61. Manal, interview, Aug. 25, 2013.

62. Noha, interview, Nov. 20, 2013.

63. Leila, interview, Dec. 5, 2013.

64. Ibid.

65. Shady, interview, Dec. 10, 2013; Passant, interview, Nov. 20, 2013. 
superficially, ${ }^{66}$ others more significantly, re-examining their initial views; all interviewees noted a number of initially skeptical male volunteers changed their minds to some extent. Describing female teammates' abilities, they used vocabulary typically associated with hegemonic masculinity; many explained this experience showed them the boundaries between gender roles could be more fluid than they had thought. All those interviewed who did not initially define themselves as feminists, mentioned having given thought to how gender identities are defined. Many noted an improved understanding of how sexual harassment and assault function in the public sphere, and of a connection between these issues and dominant models of gender. One reported rethinking his views on gender entirely:

"I saw there were some girls [in our team] who worked better than ten guys put together. I started to think about it differently: why am I judging people based on gender? Eventually I became so convinced [gender stereotypes are wrong] that when I was put in charge of Intervention teams' training sessions, ...I'd tell them 'No, there have to be girls on the teams.' When some people opposed this, I got angry and forgot I used to be like them." ${ }^{67}$

His case cannot be considered representative of the majority of male volunteers. Nonetheless, "despite the persistence of some reactionary discourse... the experience forced participants to engage with many difficult issues related to men's conceptions of their own roles and those of women," noted researchers Dalia 'Abd al-Hameed and Hind Ahmed Zaki. ${ }^{68}$

Several volunteers noted that male teammates whose approach to gender roles ostensibly changed within the OpAntiSH social sphere, could revert to some version of their initial attitudes outside it. Yet not all such changes in manner were perceived negatively by female peers who were also their friends:

"It's nice, with Ahmad, that when we're in OpAntiSH there's that egalitarian side, but when we're walking in Tahrir on a non-OpAntiSH day, that [idea he should protect women] is back... I know he doesn't totally "get it", although at the same time, I don't totally "get it" either... So I'm fine with it. But it's nice that in that [OpAntiSH] space I can suspend my disbelief, and he can suspend that disbelief and we can have a very equal kind of dynamic. And we can revert back later, or not, but we have that space." 69

This provides a reminder of how deliberately individuals can modulate their performance of gender, and of the complexity of gender identity. 
Ultimately, as Passant noted above, she and Ahmad now "have that space" that OpAntiSH has created. Even if the collective were never to function again, volunteers have been introduced to a form of collective action integrating men and women equally and challenging patriarchal definitions of gender roles. That cannot be undone.

Operation Anti-Sexual Harassment/Assault was created to fight sexual violence and defend women's right to political expression in the public sphere, without reinforcing the patriarchal concept of women needing "protection" from men. OpAntiSH's encouragement of female volunteers to participate in the entire process of rescuing mob assault survivors was one of various factors that motivated women to volunteer for Intervention. Though many male volunteers were initially skeptical about mixed-gender teams, some changed their minds to various degrees; although some gender-related differentiation persisted, volunteers' views of gender roles evolved continuously, as women "proved themselves" to their peers, and gender dynamics within teams were negotiated in various ways.

OpAntiSH's purpose and the way it functioned fostered debate about women's participation, which "also generated a fundamental consciousness of the values of feminist solidarity, and about women's responsibility for one another and their recognition of it." 70 Though it did not direct explicitly feminist rhetoric to the public, the group introduced some of its members to feminist ideas through the way it functioned. "We are proving the power of women," 71 one observed. As volunteers contested traditional gender roles, the group's activity helped its members question some of their previous assumptions and gain awareness of gender relationships in the public sphere in general. As Leila and others remarked, part of OpAntiSH's importance lies in how it generated a social sphere in which egalitarian gender norms were asserted and enforced through explanation, negotiation and practice; it has been "an exceptional experience of building something on the ground that is feminist in Egypt." 72

70. Zaki \& Abd elHameed, 2014.

71. Mona, interview, Dec. 9, 2013.

72. Leila, interview, Dec. 5, 2013. 


\section{REFERENCES}

Amar, Paul. Turning the Gendered Politics of the Security State Inside Out? International Feminist Journal of Politics 13(3), p. 299-328.

Amnesty International, "Egypt: Gender-based violence against women around Tahrir Square," (doc. Index Number: MDE 12/009/2013), Feb. 6, 2013, http://www.amnesty.org/en/library/info/MDE12/009/2013/en. Accessed Aug. 26, 2014.

Amnesty International. "Egypt Law-makers Blame Women Victims for Sexual Violence," Public Statement (Index: MDE 12/010/2013), Feb. 13, 2013, http://www.amnesty.org/en/library/asset/MDE12/010/2013/en/8a596aea4950-4313-9b44-0ee1dd3815b7/mde120102013en.html. Accessed Aug. 26, 2014.

Connell, R. W. (1987) Gender and Power. Sydney: George Allen \& Unwin.

Connell, R. W. \& Messerschmidt, James W. Hegemonic Masculinity: Rethinking the Concept. Gender and Society 19:6 (Dec. 2005), p. 829-859.

Dutta, Debolina \& Sircar, Oishik. India's Winter of Discontent: Some Feminist Dilemmas in the Wake of a Rape. Feminist Studies 39 (1 20), 2013, p. 293-306.

Egypt Independent, "Shura Council committee says female protesters should take responsibility, if harassed," Feb. 11, 2013. http://www.egyptindependent. com/news/shura-council-committee-says-female-protesters-should-takeresponsibility-if-harassed. Accessed Aug. 26, 2014.

El-Sadda. H. Women's rights activism in post-Jan25 Egypt: Combating the Shadow of the First Lady Syndrome in the Arab World. Middle East Law and Governance 3, p. 84-93, 2011.

Gupta, Amith. Orientalist Feminism Rears Its Head in India. Jadaliyya, Jan. 2, 2013, http://www.jadaliyya.com/pages/index/9371/orientalist-feminismrears-its-head-in-india, Accessed May 3, 2015.

Hafez, Sherine. The Revolution Shall Not Pass Through Women's Bodies: Egypt, Uprising and Gender Politics. The Journal of North African Studies, 19(2): 172-185, 2014.

Hatem, Mervat. Gender and Revolution in Egypt. Middle East Research and Information Project (MERIP) 261, 2011, http://www.merip.org/mer/ mer261/gender-revolution-egypt. Accessed May 3, 2015.

Human Rights Watch, "Egypt: Epidemic of Sexual Violence," Public Statement and video, July 3, 2013, http://www.hrw.org/news/2013/07/03/egypt-epidemic-sexual-violence. Accessed Aug. 26, 2014.

Human Rights Watch, "Égypte : Agressions sexuelles sur la place Tahrir" (video), July 12, 2013. https://www.youtube.com/watch?v=ZgQIltQ58FY. Accessed Aug. 26, 2014.

Kadry, Ahmed. Gender and Tahrir Square: contesting the state and imagining a new nation. Journal for Cultural Research, 2014. Available online at http:// dx.doi.org/10.1080/14797585.2014.982922 Accessed Dec. 21, 2014. 
Kirollos, Mariam. Sexual Violence in Egypt: Myths and Realities. July 16, 2013, http://www.jadaliyya.com/pages/index/13007/sexual-violence-in-egypt_ myths-and-realities-. Accessed Aug. 26, 2014.

Krishnan, Kavita. "Sexual Violence in India - A Conversation Between Kavita Krishnan and Brinda Gangopadhya Lundmark," undated interview, http:// www.hystericalfeminisms.com/sexual-violence-in-india/. Accessed May 3, 2015.

Langohr, Vickie. This Is Our Square. Fighting Sexual Assault at Cairo Protests. Middle East Report 268, fall 2013. http://www.merip.org/mer/mer268/oursquare. Accessed Aug. 26, 2014.

New President, Old Pattern of Sexual Violence in Egypt. Middle East Report, July 7, 2014. http://www.merip.org/mero/mero070714 Morsi, Maya. Egyptian women and the 25th of January Revolution: presence and absence. The Journal of North African Studies 19(2), p. 211-229, 2014.

Mukherji, Anahita. 'Don't tell me how to dress, tell them not to rape'. The Times of India, May 5, 2012, http://timesofindia.indiatimes.com/city/delhi/ Dont-tell-me-how-to-dress-tell-them-not-to-rape/articleshow/13008664. cms. Accessed May 3, 2015.

Nazra for Feminist Studies. "ورقة موقف حول العنف الجنسي ضد النساء وارتفاع معدلات الاغتصاب "الجماعي بميدان التحرير والمناطق المحيطة Women and High Rates of Mass Rape in Tahrir Square in the Surrounding Areas"), Feb. 4, 2013, http://nazra.org/node/196. Accessed Aug. 26, 201.4 Concept Paper: Different Practices of Sexual Violence Against Women (English), 2014. http://nazra.org/en/2014/02/concept-paper-different-practices-sexual-violence-against-women.

"First Verdict in Cases of Mob-Sexual Assault and Gang Rape in Tahrir Square Is No End to the Story." July 19, 2014. http://nazra.org/ en/2014/07/first-verdict-cases-mob-sexual-assault-and-gang-rape-tahrirsquare-no-end-story. Accessed May 3, 2015.

Operation Anti-Sexual Harassment/Assault, "هذا هو الاعتداء الجماعي.. احنا هنقاوم" ("This is Sexual Assault. We Will Resist" - video in Ärabic with English subtitles), Feb. 1, 2013, http://www.youtube.com/watch?v=KZyo74ESr2s. Accessed Aug. 26, 2014.

Pratt, Nicola. Gendered paradoxes of Egypt's transition. Open Democracy, 2 Feb. 2015, https://www.opendemocracy.net/5050/nicola-pratt/genderedparadoxes-of-egypt\%E2\%80\%99s-transition Accessed 3 Feb. 2015.

Skalli, Loubna Hanna. 2014. Young Women and Social Media Against Sexual Harassment. Journal of North African Studies, 19(2): 244-258.

Tadros, Mariz. 2014. Reclaiming the Streets for Women's Dignity: Effective Initiatives in the Struggle Against Gender-Based Violence in Between Egypt's Two Revolutions. Institute of Development Studies Evidence Report no.48, http://opendocs.ids.ac.uk/opendocs/bitstream/handle/123456789/3384/ER48. pdf; jsessionid=AA65EDA53D53E69A8D82D853B99176D2 ? sequence $=1$ Accessed 3 Feb. 2015. 
. 2013a. Whose Shame Is It? The Politics of Sexual Assault in Morsi's Egypt. Heinrich Boll Stiftung, Afrique Du Nord Tunis, http://tn.boell.org/ downloads/MarizTadros.pdf. Accessed 3 Feb. 2015.

2013b. Politically Motivated Sexual Assault and the Law in Violent Transitions: A Case Study From Egypt. Institute of Development Studies, Evidence Report no. 8, http://opendocs.ids.ac.uk/opendocs/bitstream/ handle/123456789/2950/ER8\%20final\%20online.pdf?sequence=1\&utm source=idswebsite\&utm_medium=download\&utm_campaign=opendocs Accessed 3 Feb. 2015.

Understanding Politically Motivated Sexual Assault in Protest Spaces: Evidence from Egypt (March 2011 to June 2013). Social \& Legal Studies 1-18, 2015.

UN Women, HarassMap et al. Study on Ways and Methods to Eliminate Sexual Harassment in Egypt. 2013. http:/www.dgvn.de/fileadmin/user_upload/ DOKUMENTE/English_Documents/Sexual-Harassment-Study-EgyptFinal-EN.pdf Accessed May 3, 2015.

Winegar, Jessica. The privilege of revolution: Gender, class, space, and affect in Egypt. American Ethnologist 39 (1): 67-70, February 2012.

Zaki, Hind Ahmad \& Abd elHameed, Dalia. استباحة-النساء-في-المجال-العام (Estibaha(t) al-Nisa' fi-I-Majal al-'Amm), 2-part article, Jan. 8-10, 2014, http://www.

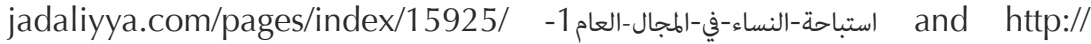
www.jadaliyya.com/pages/index/15944/ استباحة-النساء-في-المجال-العام-المال-2. Accessed Aug. 26, 2014. Note: the first part is available in English translation: "Women As Fair Game in the Public Sphere: A Critical Introduction for Understanding Sexual Violence and Methods of Resistance", Jadaliyya, July 9, 2014, http://www.jadaliyya.com/pages/index/18455/women-asfair-game-in-the-public-sphere_a-critical Accessed Aug. 26, 2014. 